Bennett's Herald are listed as small dailies. Reading the list of city officials, one is struck by the character of the names, which run to Pearsalls, Allisons, Westcotts, and Schuylers, with an isolated Ahearn and Haggerty the exception rather than the rule. De Witt Clinton's name appears three times as mayor.

Toward the back of the book are regulations to be observed by the drivers of carriages and hackney coaches, for the fees of public porters and for the fees of chimney sweepers. Among other prohibitions, hackney coaches were not allowed to charge more than seventy-five cents for conveying a passenger to the New Alms House, and returning. Under amusements, there is a list of some five theatres, an increase of four over I807. It is to be hoped that these were equal to the original Playhouse in their interior finish and decoration, for there "the boxes were exceedingly well adapted to the display of beauty and fashion, as well as to the view of the scenic performances." There were two museums, and two principal baths for the accommodation of strangers and citizens, besides many others of lesser note. A favorite excursion was to Hoboken, a popular summer resort, and another to Coney Island, where there was a fine beach for bathing, with a public house, and other conveniences. The Battery appears as a beautiful promenade; its eleven acres laid out in grass-plots and gravel walks, and shaded with trees, with an expensive iron railing extending along the interior front, "justly commanding the admiration of every visiter." Perhaps the student of our past in its social and industrial phases can glean from the detailed and casual description in a small year book like this as vivid and intimate an impression of little old New York as from a more pretentious work.

\title{
The Society Captures the Golden Fleece
}

"The Golden Fleece; or the Trade, Interest, and Well Being of Great Britain," a recent acquisition of The Business Historical Society, is a rare pamphlet dated 1736 , which gives a contemporary summary of the wool situation in the seventeenth and early eighteenth centuries. From the time of Edward III, the petted woollen industry, for so long the pride of Britain, enjoyed the protection of the government. It was not until the seventeenth century, however, that the manufacture of woollen goods came to be-protected and fostered at all costs. Raw wool was not allowed to leave the 
country, for, by keeping it at home, the jealous English hoped to starve rival manufactures on the Continent by cutting off their chief supply of raw material. The high prices offered in France, in particular, were a temptation not to be resisted "by such who only measure their conscience by their gain," so that the problem of the smuggling trade was an ever-present one. "The methods and ways of these evils," says William Carter, a contemporary writer, of the smugglers, or "owlers," "are - first, in Romney Marsh, in Kent, where the greatest part of rough wool is exported from England, put aboard French shallops by night, ten or twenty well-armed men to guard it. ... The same for combed wool from Canterbury; they will carry it ten or fifteen miles at night toward the sea - with like guard as before." The "owlers" are said to have shipped 40,000 packs to Calais alone, from the coasts of Kent and Sussex, and they grew "monstrous rich by that wicked trade."

The favorite remedy for the situation was a scheme to register the wool at shearing time, and then keep close track of it until the final stage of making into cloth. This expensive procedure was proposed in 1717 , and again some years later, when the House of Commons passed a resolution in its favor, but nothing further seems to have been done.

The "Golden Fleece" is a plea for this plan, prefaced by a statement of the case of the manufacturers, illustrated by references to the traditional policy of "our ancestors, who wisely foresaw, how fatal and destructive the exporting unwrought Wool might prove to their Kingdoms, if our Neighbors, by our Help, should set up Woollen Manufacturies, and by living more frugally than the English, and having Labour and Provisions cheaper could supply not only themselves, but other more remote Nations, with Woollen Goods, at a lower Price, which without our Wool, must have been purchased of us, at our own Price; hereby many thousands of WoolCombers, Clothiers, Carders, Spinners, Dyers, and others, would, for want of Employment, become a grievous Burthen to their native Country." The writer adds that a small tax on wool would supply the revenue now gleaned from "some of the most essential necessaries of life, viz. Leather, Soap, Candles, Painted Silks, and Starch." This new tax would relieve the makers of these essential necessaries from the irksome inspection of their products throughout the process of manufacture, lower the cost of living, and so enable the woollen manufacturers to reduce wages and compensate themselves for the tax. 
After profuse statistics on the losses sustained by the country through the smuggling trade, he explains the plan he advocates. The officers employed in collecting duties on leather, soap, etc., could register the wool instead, and the tax could be collected when the wool was cut from the sheep's back. After that, licenses could be required at each step in manufacturing. Another much-debated question is taken up in the pamphlet, to wit, should Ireland be allowed to compete with England in the woollen market? The English were as jealous of Ireland, with its cheaper labor and consequent lower prices, as though it had been a foreign country. It is proposed by the author of the "Golden Fleece" to forbid the Irish to sell either wool or finished woollen goods outside the British Isles, and to admit both to England free of duty. From the fact that the "Specie of Ireland are chiefly Moidores, Doubloons, and Pieces of Eight," he infers that the trade of Ireland is largely with Spain and Portugal. His plan is to have "register ships" carry all woollen goods from Ireland, and if adverse winds blow one of these on a foreign coast, it is to be sunk, if that is possible without danger to those on board, rather than that the cargo should fall into the hands of the foreigners.

By the foregoing plan, the simple moving of some government officials from one employment to a similar one was to be the means of suppressing smuggling, and England, hermetically sealed to outgoing wool, was thus to be assured of supremacy in the woollen market, hence of a favorable balance of trade, and by this latter, of the foremost place among nations.

\section{More Stock Exchange Figures than the Stock Exchange}

Extensive use of the Business Library's collections of early Boston and New York stock exchange prices has been made by the National Bureau of Economic Research for its forthcoming study of "Bond Yields and Interest Rates" for the last seventy years. It was found that the Library's set of official stock exchange records dated back as far as I 857 , whereas the material in the New York Public Library and the New York Stock Exchange is not earlier than January, I 859. 